\title{
PROVOCATION: TO BE OR NOT TO BE AN ATTRIBUTED CHARACTERISTIC
}

\author{
Simon Parsons*
}

There is currently disagreement as to when a characteristic of the defendant can be attributed to the reasonable man in the objective question in the defence of provocation before that question is considered by a jury. The issue is whether there is a distinction between provocability (impaired self-control) and provocativeness (increased sensitivity). It has been strongly argued that, when considering whether a defendant has complied with the standard of self-control which is required if provocation is to be established in law, characteristics such as the defendant's explosive temperament must be excluded from the objective question, as these relate to self-control. ${ }^{1}$ In contrast, individual characteristics which go to the gravity of the provocation should be included as these increase the defendant's sensitivity to the provocation. This article will argue that decisions of the House of Lords and the Privy Council have developed and maintained this distinction whilst decisions of the Court of Appeal have not. The reasons for this conflicting case law will also be considered.

Section 3 of the Homicide Act 1957 provides:

"Where on a charge of murder there is evidence on which the jury can find that the person charged was provoked (whether by things done or by things said or by both together) to lose his self-control, the question whether the provocation was enough to make a reasonable man do as he did shall be left to be determined by the jury; and in determining that question the jury shall take into account everything both done and said according to the effect which, in their opinion, it would have on a reasonable man."

Provocation is a special or partial defence in that it reduces a killing that would

"Senior Lecturer in Law, Southampton Institute. I am grateful to Howard Davies, Georgina Andrews and an anonymous reviewer for their helpful comments on an earlier draft of this article.

1 A.Ashworth, "The Doctrine of Provocation" [1976] C.J.L. 292 at pp.299-300. 


\section{THE DENNING LAW JOURNAL}

have been murder $^{2}$ to voluntary manslaughter and thus gives a judge discretion when sentencing. The defence involves two questions. First was the defendant provoked to kill? ${ }^{3}$ Second, would a reasonable man in the same circumstances been provoked to "do as [D] did?"4 The burden of proof is on the prosecution so for the defence to succeed the jury must hold a reasonable doubt on both questions.

\section{THE SUBJECTIVE QUESTION'}

The first question for a jury to consider is whether the defendant was provoked to lose his self-control. ${ }^{5}$ The defendant need not completely lose his self-control in the sense that he did not know what he was doing, it being sufficient that he became so angry that he was unable to restrain himself. ${ }^{6}$ If the defendant lost his self-control for some other reason, for example, revenge or fear, then the defence will not be available to him. ${ }^{7}$ The jury can take into account all the defendant's characteristics when considering this question because they will be able to consider the relevant evidence which will include those characteristics. The provocation must amount to specific words or conduct or both, as the jury must have an idea what the provocation was, otherwise it will be asked to do the impossible when considering the objective question - the reaction of the

\footnotetext{
${ }^{2}$ Provocation is available as a defence only to a murder charge although this includes an accomplice to murder

3 The provocation need not be illegal or wrongful but can amount to, for example, a baby crying: Doughty (1986) 83 Cr.App.R. 319.
}

"This should, it is submitted, mean "to kill" and not "to kill and act as D did after the killing" because conduct after the killing should be irrelevant but the Court of Appeal in Clarke [1991] Crim. L.R. 383 objected to this view. In that case the defendant strangled the victim and then electrocuted a corpse. The Court of Appeal held that there was no limitation to the words "do as he did" and the electrocution should be considered.

5 The provocation does not necessarily have to originate from the victim. Provocation can originate from third parties (Davies [1975] Q.B. 691) or be directed at third parties:Pearson [1992] Crim.L.R. 193.

${ }^{6}$ Richens (1994) 98 Cr.App.R. 43.

7 Thus it appears that the underlying emotion accompanying a loss of self-control is limited to anger which tends to be a male emotion rather than female. However why should not fear be the underlying emotion? This point has not been considered by the Court of Appeal or the House of Lords, although the High Court in Australia has commented: "No doubt it is true to say primarily anger is a feature of provocation and fear a feature of self-defence. But it is too much to say that fear caused by an act of provocation cannot give rise to a defence of provocation." Van den Hoek v. R. (1986) 161 C.L.R. 158 at 167. 
reasonable man to unknown provocation. ${ }^{8}$

\section{THE OBJECTIVE QUESTION.}

The jury may determine that there is a reasonable possibility that the defendant was provoked to lose his self-control when he killed. This does not mean the defendant will succeed in the defence unless the jury is also satisfied that there is also a reasonable possibility that "the provocation was enough to make a reasonable man do as he [the defendant] did." Before this second question can be considered by a jury the judge will need to direct it as to which of the defendant's characteristics can be attributed to the reasonable man. This is the source of conflict between the Court of Appeal on the one hand and the House of Lords and the Privy Council (at least a majority in the Privy Council) on the other.

In Bedder $v$ DPP the House of Lords held that the reasonable man was an ordinary normal adult person, thus a purely objective test was imposed. ${ }^{10}$ So if the defendant was a juvenile he was disadvantaged, as the self-control of an adult person would be expected of him. In addition the common law rule was that provocative occurrence was limited to acts of violence by the victim upon the defendant. Thus there was no need to consider provoking words, so if the defendant was provoked about, for example, his impotence that characteristic could not be attributed to the reasonable man when applying the objective test.

Section 3 of the Homicide Act 1957 amended the common law in three ways. First, it allowed words alone to constitute provocation. Second, it consequently allowed the defendant's characteristics to be taken into account when applying the objective test. Third, if there is any evidence of provocation, a judge has a duty to leave the defence of provocation to the jury. "In Camplin the House of Lords held that the decision in Bedder required revision in view of these changes made to the common law. ${ }^{12}$ In Camplin the victim forcibly buggered the defendant, who was a fifteen year old boy, and then laughed at him. This provoked the defendant to lose his self-control so that he hit the victim over the head with a chapati pan killing him. On appeal to the House of Lords, Lord

${ }^{8}$ Acott [1986] Crim.L.R. 664.

${ }^{9}$ S.3 of the Homicide Act 1957

${ }^{10}$ [1954] 1 W.L.R. 1119.

1 Even if the judge is satisfied that any reasonable jury would be sure that the provocation would have not provoked a reasonable man to kill. A defendant has a right to a perverse verdict although loss of this right has no redress on appeal: Dhillion [1997] Crim.L.R. 295 12 [1978] A.C. 705 


\section{THE DENNING LAW JOURNAL}

Diplock stated:

"[a] proper direction to a jury... should state... that the reasonable man referred to in the question is a person having the power of self-control to be expected of an ordinary person of the sex and age of the accused, but in other respects sharing such of the accused's characteristics as they think would affect the gravity of the provocation to him; and that the question is not merely whether such a person would in like circumstances be provoked to lose his self-control but also whether he would react to the provocation as the accused did." 13

It is the use of this direction as an interpretation of the objective question in section 3 which has led to the conflicting case law. However, there is some agreement in that the courts agree that age is relevant in the assessment of the level of the standard of self-control which has to be complied with, if provocation is to be established in law. Thus, a lower level of self-control is expected of a juvenile compared to that of an adult. The relevance of gender or sex to selfcontrol is not wholly clear but if the social conditioning of women not to react with violence is relevant then a higher standard of self-control would be expected. But this breaches the principle of equality before the law and the High Court of Australia has rejected this view, holding that only age is relevant to the level of self-control to be expected. ${ }^{14}$

It is the second possible use of the direction as an interpretation of section 3 which has led to the tension between the courts. Two years after Camplin came the Court of Appeal decision of Newell. ${ }^{15}$ In Newell the defendant's girlfriend had left him because of his alcoholism. The defendant became grief stricken and attempted suicide. Having survived a suicide bid, the defendant went to the victim's flat where they both drank a substantial amount of alcohol. The defendant was explaining to the victim how devastated he was when the victim said: "Why don't you forget that fucking bitch; she's no fucking good for you. Why don't you come to bed with me?"16 This provoked the defendant to hit the victim over the head with a heavy ashtray at least twenty times, killing him. The Court of Appeal relied on an obiter dictum of North $\mathbf{J}$. in the New Zealand

13 Ibid at 718 .

14 Masciantonio (1995) 69 A.L.J.R. 598; Stingel (1996) 20 Crim. L.R. 72.

15 (1980) 71 Cr.App.R 331.

16 Ibid at 333 
decision of McGregor ${ }^{17}$ for sole guidance for the meaning of Lord Diplock's direction in Camplin. North J. stated:

"[t]he characteristics must be something definite and of sufficient significance to make the offender a different person from the ordinary run of mankind, and have also a sufficient degree of permanence to warrant its being regarded as something constituting part of the individual's character or personality ... [It covers] not only ... physical qualities but also... mental qualities and such more indeterminate attributes as colour, race and creed... Moreover... there must be some real connection between the nature of the provocation and the particular characteristic of the offender by which it is sought to modify the ordinary man test. The words or conduct must have been exclusively or particularly provocative to the individual because, and only because, of the characteristic."

The Court of Appeal found this to be "impeccable"19 and applied it by not allowing the defendant's grief to be taken into account when considering whether an ordinary person would have been provoked by the victim's disparaging remarks about the girlfriend. The reason must be that the grief was only a transitory phenomenon and not permanent and thus had to be excluded. However in Camplin Lord Simon had stated the "entire factual situation"20 is relevant to the assessment of the gravity of the provocation and in Morhall ${ }^{21}$ Lord Goff criticised the requirement that characteristics had to be permanent stating that transitory physical conditions (such as eczema) should be taken into account if the subject of taunts. ${ }^{22}$ The conclusion must be that the Court of Appeal was wrong to exclude the defendant's grief from the assessment and such exclusion was prejudicial to the defendant. ${ }^{23}$

17 [1962] N.Z.L.R. 1069.

18 Ibid at 1081-1082.

19 Supra n. 15 at 340.

20 Supra n. 12 at 727. Approved by Lord Goff in Morhall [1995] 3 All E.R. 659 at 665. Thus if the defendant is a battered woman (whether suffering from battered woman syndrome or not) and there is a history of battering which increases the gravity of the provocation of the last case of violence then the ordinary person in the objective question should be subject to that history.

2! [1995] 3 All E.R. 659.

22 Ibid at 667

23 The Court of Appeal was right to exclude the defendant's chronic alcoholism as that 
The decision in Newell has influenced other decisions of the Court of Appeal. In Ahluwalia Lord Taylor confirmed that a permanent characteristic relating to the mental state or personality of an individual could be taken into account by a jury when applying the objective test. ${ }^{24}$ In Dryden ${ }^{25}$ Lord Taylor held that the defendant's obsessional behaviour was a relevant characteristic. ${ }^{26}$ In Humphreys ${ }^{27}$ Lord Justice Hirst held that the defendant's abnormal immaturity was permanent and therefore a relevant characteristic. ${ }^{28}$ In Thornton (No.2) ${ }^{29}$ Lord Taylor held that battered woman's syndrome and the defendant's personality disorder were relevant characteristics. ${ }^{30}$ All these decisions quote North J.'s dictum but only apply the first part of it relating to the permanence of the characteristics. The latter proviso requiring that the characteristics go to the gravity of the provocation is not applied.

This has not been accepted as good law as in the Privy Council decision of $L u c$ Thiet Thuan $\vee R^{31}$ Lord Goff criticised Newell for "the wholesale adoption, without analysis, of a substantial part of [North J's] obiter dictum",32 because that dictum interpretated a New Zealand statute which provided for a provocation defence ${ }^{33}$ but not a separate defence of diminished responsibility. ${ }^{34}$ Thus the influence of Newell on the subsequent Court of Appeal decisions in Ahluwalia, Dryden, Humphreys and Thornion (No.2) is "to incorporate the defence of diminished responsibility indirectly into the law of provocation"35 with the result of transforming "the objective approach,recognised by the United Kingdom Parliament in 1957, into a subjective approach, though doubtless having the

\footnotetext{
characteristic did not go to the gravity of the provocation: Supra n. 15 at 340 .

24 [1992] 4 All E.R. 889 at $897-898$.

${ }^{25}$ [1995] 4 All E.R. 987.

26 Supra n.25 at 998 . This was obiter as the Court found that the defendant had not lost his self-control.

27 [1995] 4 All E.R. 1008.

28 Ibid n.27 at 1022 . This means that there is no distinction between chronological age and immaturity as both can be taken into account even though both do not go to the gravity of the provocation. The appeal was allowed and a conviction for manslaughter substituted. Upon release the defendant died of a drug overdose having become addicted to prescribed tranquillisers in prison.

29 [1996] 2 All E.R. 1023.

30 Ibid at 1031.

${ }^{31}$ [1996] 2 All E.R. 1033.

32 Ibid at 1043.

33 New Zealand Crimes Act 1961 s. 169

${ }^{34} C f$. s. 2 of the Homicide Act 1957 and s. 3 of the Hong Kong Ordinance.

35 Supran.31 at 1046.
} 


\title{
PROVOCATION: ATTRIBUTED CHARACTERISTICS
}

effect of excluding cases of intoxication and bad temper. ${ }^{.36}$ The further complication which flows from this approach is that with diminished responsibility the burden of proof (the civil burden) is on the defendant and thus:

\begin{abstract}
"[i]f diminished responsibility was held to form part of the law of provocation, the extraordinary result would follow that a defendant who failed to establish diminished responsibility... might nevertheless be able to succeed on the defence of provocation ... on the basis that, on precisely the same evidence, the prosecution failed to negative, on the criminal burden, that he was suffering from a mental infirmity affecting his self-control which must be attributed to the reasonable man for the purposes of the objective test. ${ }^{37}$
\end{abstract}

This leads on to the crucial question in this article - what is the nature and purpose of the objective test? The explanation of Lord Diplock's direction by Lord Goff in Morhall and Luc Thiet-Thuan can be taken to indicate that any characteristic is relevant to the assessment of the gravity of the provocation even if that characteristic is discreditable ${ }^{38}$ It is submitted that this reasoning was influenced by Professor Ashworth's conclusion made in 1976 that:
"[t]he proper distinction... is that individual peculiarities which bear on the gravity of the provocation should be taken into account [provocativeness], whereas individual peculiarities bearing on the accused's level of self-control should not [provocability] ${ }^{239}$

This means that where a defendant loses his self-control as a result of being provoked about one of his characteristics, that characteristic should be taken into account when applying the objective test so that a proper assessment of the seriousness or gravity of the provocation can take place. Thus, for example, if the

${ }^{36}$ Supra n.31 at 1047-1048. Cf. New Zealand where in McCarthy [1992] 2 N.Z.L.R. 550 Cooke J. considered that s. 169 of the New Zealand Crimes Act 1961 had the legislative purpose of introducing diminished responsibility into the defence of provocation and because of this the second part of North J.'s obiter dictum was wrong.

37 Supra n.31 at 1046.

38 Discreditable characteristics would include alcoholism but not the fact the alcoholic defendant was the worse for drink at the time of killing :Morhall [1995] 3 All E.R. 659 at 666-667.

39 Supra n. 1 at p. 300 


\section{THE DENNING LAW JOURNAL}

defendant is taunted about his sexuality then this will be a relevant characteristic to be attributed to the ordinary person as it bears on the gravity of the provocation, whereas if he is taunted about his nationality, his sexuality would be irrelevant. Why has this distinction been made? One possible answer is that the objective component of Lord Diplock's direction is the ordinary person's power of self-control. In Morhall Lord Goff stated that "[t]he function of the [reasonable man] test is only to introduce as a matter of policy, a standard of self-control which has to be complied with if the provocation is to be established in law. ${ }^{340}$ The policy underlying the objective question is to reduce the occurrence of fatal violence by stopping a person relying on his exceptional pugnacity or excitability as an excuse for the loss of self control. ${ }^{41}$ According to this view, by allowing mental characteristics to be attributed to the ordinary person, when such characteristics do not go to the gravity of the provocation, the Court of Appeal is confusing provocability with provocativeness. This means that the distinction between the subjective and the objective questions is breaking down, because the objective application of the ordinary person's power of selfcontrol is being eliminated.

Lord Goff states that this approach should be halted and the distinction between provocability and provocativeness should be maintained. ${ }^{42}$ However, in his dissenting judgment in Luc Thiet Thuan $\mathrm{v} R$ Lord Steyn maintains that the Court of Appeal decisions are right in that " $\mathrm{t}$ ] he law remains that a defendant may not call in aid his own irascibility or pugnacity... that does not mean it was right to ask the jury to ignore the defendant's brain damage. ${ }^{243}$ This has received academic criticism:

"A jury may well wonder whether there is any difference between an eccentric and highly abnormal obsessional personality and an explosive one, especially when the personality is being advanced as the reason why the defendant "blew up". Can we really distinguish between irascibility and the various mental conditions which give rise to irascibility? It seems that Lord Steyn's opinion would virtually eliminate the distinction between the subjective and objective tests. ${ }^{\text {44 }}$

Supra n.21 at 665.

${ }^{41}$ Supra $\mathrm{n} .12$ at 716 per Lord Diplock.

${ }^{42}$ Supra $\mathrm{n} .31$ at 1045

${ }^{43}$ Supran 31 at 1055

${ }^{44}$ J.C. Smith in the commentary to Humphreys [1996] Crim L.R. 432 at p.434. 
But is this really the case? There is support for the view that a qualified objective condition is possible, even though the defendant's mental condition is taken into account, in that there is not an unquestioning acceptance of defendant's inability to exercise self-control. The inability to exercise self-control has to be reasonable for that defendant ${ }^{45}$ The question is what is the precise nature of this objective element? It must involve the jury applying their common experiences of such mental conditions, however these are likely to be limited to that of the defendant. It appears, therefore, that this interpretation will compel the jury to apply the subjective question twice which is a nonsense. It is submitted that the real effect of the Court of Appeal decisions is to lower the standard of self-control required for those unfortunate enough to suffer from incapacitating mental conditions. It could be argued that this is consistent with allowing a lower standard for young people but, unlike New Zealand law, English law allows for the separate defence of diminished responsibility and:

"[t]he distinction between the two [provocation and diminished
responsibility] ought logically be based on causal grounds. Where
D's reaction was caused predominantly by the provocation, the
defence should be provocation [provocativeness]. Where the
reaction stemmed predominantly from some psychological or
physical condition affecting D's behaviour, the defence should be
diminished responsibility [provocability] "\$46

Unfortunately this distinction between provocativeness and provocability is not being maintained in the Court of Appeal. In $S m i t h^{47}$ it was held that the defendant's severe depressive illness which resulted in him being disinhibited should have been attributed to the reasonable man even though it did not go to the gravity of the provocation. ${ }^{48}$ A jury may well query the difference between disinhibition and exceptional pugnacity or excitability. The answer must surely be that there is no difference as a defendant's disinhibition, irascibility, pugnacity, excitability or explosiveness all have the same effect of reducing the defendant's self-control. These characteristics should be excluded as the objective question is the application of the ordinary person's power of self-

45 See A.Buchanan \& G.Virgo, "Duress and Mental Abnormality" [1999] Crim.L.R. 517 at pp.530-531. C.M.V.Clarkson \& H.M.Keating, Criminal Law Text and Materials $\left(4^{\text {th }} \mathrm{ed}\right.$, Sweet \& Maxwell, 1998) at p.334.

46 A. Ashworth, Principles of Criminal Law ( $3^{\text {rd }}$ ed., Oxford University Press, 1999) at p. 278.

47 [1998] 4 All E.R. 387.

48 Ibid at 399 


\section{THE DENNING LAW JOURNAL}

control and to do otherwise is inconsistent with section 3 of the HomicideAct.

\section{CONCLUSION}

It is submitted that the majority in the Privy Council in Luc Thiet Thuan v $R$ came to the right decision because the objective question in the defence of provocation is indeed the application of the ordinary person's power of selfcontrol and those defendants who are mentally disordered should rely on diminished responsibility. The decision in Luc Thiet Thuan has influenced trial judges, for example, in Parker where the trial judge ruled that the defendant's brain damage caused by chronic alcoholism should be excluded as he was not provoked on that condition - a decision reversed by the Court of Appeal ${ }^{49}$ However, the influence of Luc Thiet Thuan is limited since decisions of the Privy Council are not binding on the Court of Appeal but rather are persuasive precedents. If there had been five Law Lords sitting, who had displayed unanimity, the decision in Luc Thiet Thuan would have been very persuasive as it would represent the view of the House of Lords, but regrettably there were only two Law Lords and they disagreed. Thus the persuasiveness of the decision is limited and the Lord Chief Justice, Lord Bingham (as he then was) made the obiter point in Campbell ${ }^{50}$ that the Court of Appeal decisions are binding on trial judges until overruled by a House of Lords decision ${ }^{51}$ Why has the Court of Appeal continued with this approach? The answer must be so that there can be a liberalisation of the defence in favour of defendants because, having decided who the reasonable man is, the jury must then apply the objective test. That involves deciding whether there is a possibility that a reasonable man would also been provoked to lose his self-control and kill. The jury are more likely to consider there is such a possibility if the reasonable man has, for example, the defendant's disinhibition as an attributed characteristic. In effect the standard of self control required of those who suffer from mental illness is lowered below that required of capable defendants. The policy behind this approach appears to be to allow such defendants (including women who suffer domestic violence resulting battered woman syndrome ) to have their response regarded as reasonable rather than mentally abnormal as is required for the purposes of diminished

49 [1997] Crim.L.R. 760; [1997] Lexis transcript, $13^{\text {th }}$ September, 1999.

${ }^{50}$ [1997] l Cr.App.R. 199.

51 Ibid at 207. A defining decision of the House of Lords will now be forthcoming as in Smith the Court of Appeal, having followed its earlier decisions on provocation, took the unusual step of granting leave to appeal: Supra n.47 at 401; and see infra Postscript for analysis of the decision of the House of Lords in Smith. 


\section{PROVOCATION: ATTRIBUTED CHARACTERISTICS}

responsibility. The problem with the approach of the Court of Appeal is that it is eliminating the ordinary person's power of self-control and Parliament cannot have had this in mind when it enacted section 3 of the Homicide Act 1957. If the draft criminal code (Clause $58{ }^{52}$ ) were enacted the distinction between provocability and provocativeness would be maintained as the second objective limb of the clause is as follows: "(b) the provocation is, in all the circumstances (including any of his personal characteristics that affect its gravity), sufficient ground for the lose of self-control." It is hoped that the forthcoming House of Lords decision in Smith will see a return to the interpretation of section 3 given in Camplin so the distinction between provocability and provocativeness is reestablished.

\section{POSTSCRIPT}

The House of Lords has now made its decision in Smith and by a majority of three to two has upheld the decision of the Court of Appeal to quash the respondent's murder conviction. ${ }^{53}$ It is Lord Hoffman's judgment that most clearly sets out the reasons for this decision, and the other two Law Lords in the majority, Lord Slynn and Lord Clyde, agreed with his speech. Lord Hoffman acknowledges that section 3 of the Homicide Act changed the common law so that if there is any evidence of provocation a judge has a duty to leave the defence of provocation to the jury. ${ }^{54} \mathrm{~A}$ number of consequences flow form this. The first is that the jury is given not only a fact-finding function but also a normative one so that: "[t]hey were to determine not merely whether the behaviour of the accused complied with some legal standard but could determine for themselves what the standard in the particular case should be." 55 This means, in respect of the objective question, juries are to decide what, in law, amounts to provocation, and, in deciding this question, they can take account of any of the defendant's characteristics whether relevant to the gravity of the provocation or not. It would be a trespass upon a jury's province for a judge to direct them to ignore any of the defendant's characteristics when deciding whether the objective

\footnotetext{
52 "A person who, but for this section, would be guilty of murder is not guilty of murder if -

(a) he acts when provoked (whether by things done or by things said or both and whether by the deceased person or by another) to lose his self-control; and

(b) the provocation is, in all the circumstances (including any of his personal characteristics that affect its gravity), sufficient ground for the loss of self-control. (Law Commission Working Paper. No.177, 1989).

${ }_{53}$ [2000] 3 W.L.R. 654.

${ }^{54}$ Ibid at $667 \mathrm{H}-668 \mathrm{~A}$

55 Ibid at $668 \mathrm{~B}$
} 


\section{THE DENNING LAW JOURNAL}

element of provocation had been satisfied. ${ }^{56}$ If a judge did make such a direction in respect of one characteristic which the jury thought central to the question of whether the act was sufficiently provocative then "the effect of such a direction would be to withdraw the issue of provocation altogether and this would be contrary to the terms of section $3 .{ }^{.57}$ The policy behind this is the principle of compassion to infirmity which includes not only youth but to other characteristics such mental illness or indeed being a battered wife. ${ }^{58}$ The second consequence flows from the first: "the law now recognises that the emotions which may cause loss of self-control are not confined to anger but may include fear and despair." 59 Lord Diplock's "proper direction to the jury" in Camplin ${ }^{60}$ is distinguished as a specimen direction suitable only for cases like Camplin and "not a one-size-fits all direction for every case of provocation." The third consequence is that by consigning the whole of the objective element in provocation to juries there will be an overlap between provocation and diminished responsibility as a jury can no longer be told to ignore, when conisidering provocation, characteristics which may found the defence of diminished responsibility. ${ }^{62}$ Lord Hoffman's view is that this is not only what section 3 requires, but represents the reality of how the law actually operates because juries have difficulty in distinguishing between characteristics that go to the gravity of the provocation and those relating to selfcontrol ${ }^{63}$ Lord Hoffman states that a direction on provocation to a jury should avoid reference to a reasonable man, instead any explanation should be in simple language. A suggested direction is given although this is not prescribed as:
"[i]f judges are freed from the necessity of invoking the formula of the reasonable man equipped with an array of unreasonable 'eligible characteristics,' they will be able to explain the principles in simple terms.

This decision represents a confirmation of the liberalisation of the defence by the Court of Appeal in favour of defendants. It means that a lower standard of self-control will be required of those who suffer from mental illness in

s6 Ibid at $668 \mathrm{C} \& 668 \mathrm{D}$

57 Ibid at $668 \mathrm{D}$.

${ }^{58}$ Ibid at $670 \mathrm{E} \& 673 \mathrm{H}$.

59 Ibid at $673 \mathrm{H}$.

60 Supra n. 13.

61 Supra n.53 at 671E.

${ }^{62}$ Ibid at $673 \mathrm{E} \& 673 \mathrm{~F}$.

63 Ibid at $670 \mathrm{~F}, 673 \mathrm{H}, \& 674 \mathrm{~A}$.

${ }^{64}$ Ibid at $679 \mathrm{~B}$ 
comparsion to capable defendants. Lord Slynn acknowledges this:
"[i]t does enable the jury to decide whether in all the circumstances people with his characteristics would reasonably be expected to exercise more self-control than he did or put another way that he did exercise the standard of self-control which such persons would have exercised." 65

But the decision goes further than this as fear or despair are accepted as emotions that can underlie the loss of self control and it is battered women who experience these emotions when they kill their abusive partners. But there is contradiction in Lord Hoffman's speech as he states "male possessiveness and jealousy should not be acceptable reason for loss of self-control leading to homicide " $" 66$ and that a direction should be given to a jury that jealousy and obsession should be ignored when considering the objective element. ${ }^{67}$ The policy behind this is to protect the public by the law insisting that possessive and jealous men should exercise self-control. It is true that such men should exercise self-control but, if Lord Hoffman's reasoning on section 3 is correct, is it not a matter for the jury to decide? Juries can surely distinguish between the despair of a battered woman and the anger of jealous man. It is submitted that if characteristics and emotions are the province of the jury that means all characteristics and all emotions and to hold otherwise is a breach of the principle of equality before the law as such a direction would withdraw, from the jury, the issue of provocation in respect of such men. ${ }^{68}$

The liberalisation of the defence is good news in one sense because it may help to reduce the incidence of domestic violence in society and this is to be welcomed. The concern is that a question of law is being left to juries and this is going to lead to inconsistency when the criminal law should be consistent. In his dissenting speech Lord Hobhouse recognises this:
" $[t]$ he function of the criminal law is to identify and define the relevant legal criteria. It is not proper to leave the decision to the essentially subjective judgement of individual jurors who happen

\footnotetext{
${ }^{65}$ Ibid at $660 \mathrm{H} \& 661 \mathrm{~A}$.

66 Ibid at $674 \mathrm{G}$

67 Ibid

68 There may also be a breach of Article 6 of the European Convention of Human Rights- the right to a fair trial-as by section 6 of the Human Rights Act 1998 courts must act in a way which is compatible with Convention rights
} 


\section{THE DENNING LAW JOURNAL}

to be deciding the case. Such an approach is apt to lead to idiosyncratic and inconsisent decisions. ${ }^{169}$

However, the majority disagreed so there will be inconsistent decisions which means if a defendant raises the defence of provocation he or she may be faced with not having any idea as to whether the defence will succeed or not.

69 Supra n.53 at $710 \mathrm{D}$. 